\title{
A POLICY FRAMEWORK FOR THE CREATIVE PATTACHITRA ARTISANS AT THE CROSSROAD OF FINANCIAL SCARCITY AND CHANGING TRENDS
}

\author{
Pallavi KANUNGO*, Narayan SETHI, Pritam BISWAL \\ Department of Humanities and Social Sciences, National Institute of Technology Rourkela, \\ Odisha, 769008, India
}

Received 8 April 2019; accepted 2 November 2019

\begin{abstract}
The present paper introduces the handicraft known as pattachitra art, which personifies Odisha's culture and spiritual observances. Pattachitra is a renowned traditional painting of Raghurajpur village in Puri, Odisha (formerly Orissa), Eastern India. The study aims to examine the artisan's financial accessibility and the problems of financial scarcity confronted by them and to understand various approaches made by them to sustain their painting under changing trends. The study is a mixed method approach that includes a personal interview, observations, and rapid rural appraisal. It also includes SWOT analysis (strengths, weaknesses, opportunities, and threats), and $\mathrm{ABC}$ analysis, which helped to prepare a policy framework. Lastly, the paper has documented pictorial facts to show the innovative approaches adapted for sustaining this traditional art.
\end{abstract}

Keywords: artisans, changing trends, financial scarcity, Odisha, pattachitra, creative.

\section{Introduction}

Odisha is famous for creative art forms such as metalworking, silver filigree, stone carving, appliqué, and others. One among them is pattachitra, which surrounds Odisha's religiosity, culture, and spiritual observances to put life into this art. This visual art is an enthralling mix of creativity with sacredness and extends to the utility. The art blends two keywords patta (foundation, base, canvas, or any material suitable for drawing) and chitra (visual, creative designs and or artistic depiction). Earlier, the cloth was the prime canvas for this art; now it ranges from bottles, wooden plaque, clock, coconut shell, etc. The painting evolved and gained popularity with the foundation of Jagannath Temple Puri, Odisha. The history of painting holds its prominence in the showering service i.e. Debasnana Purnima of Lord Jagannath (Mohanty, 2011). Thus, such recognition with the Jagannath cult creates a strong tie of divine and cultural status. Apart from colourful paintings, another form exists i.e. the delimited and minute drawings on the palm leaf, which also enhances Odisha's sociocultural

*Corresponding author. E-mail: pallavi.kanungo.pk3@gmail.com 
concords for example - Lord Ganesha with auspicious hymns, Odia literature, and horoscopes of newborns.

In Odisha, pattachitra artisans known as chitrakaras (pattachitra artisans), mostly belong to the Raghurajpur village in Puri district. The village is the one and only in India with families engaged in the various type of crafts. The chief crafts are namely pattachitra paintings, palm-leaf manuscripts, papier-mâché, cow dung toys, and tussar silk paintings; others crafts are stone carving, wood carving, and wooden toys. Through a moderate developmental process, pattachitra emerged as a way of livelihood. However, in a technocratic era, its attractiveness has turned superfluous. Hence, the present work aims to examine the artisan's financial accessibility and the problems of financial scarcity confronted by them; and to understand various approaches made by them to sustain their painting under changing trends. Lastly, the paper draws an anticipated policy framework with suggestions, which will possibly improve the livelihood of artisans and sustain their art form.

\section{Review of literature}

An adequate number of studies exist on this topic, chronicled by the national and international forum. A national handicraft is similar to the writings about one's own nation. Handicrafts are the objects made by artistic hands or through the use of primitive, homemade, and simple tools. They are the outcomes, which is for household utility or home decoration (Upadhyay, 1976; Ministry of Textiles, 1989). Patta paintings have originated from Puri district of Odisha. These artisans namely chitrakara, are the descendants of the artisans who had painted during the era of Buddhists and Jains. The patta paintings are unique because it expresses the religious traditions of Odisha and especially the culture of Jagannath in Puri temple (Pathy, 1990; Mitra, 1875, 1880; Kanungo, 1964; Kanungo, 2013). It is used in education, as the medium of communication, entertainment and mainly for religious practices.

However, certainly, it has failed to project itself and gain the deserved prominence. Moreover, the units suffering from poor financial health need policies to revive. Such barrier challenges its substantial progress. Odisha crafts are facing problems due to the encroachment of machine-based patta, inexpensive but of poor quality. This situation compels the artisans to shift their profession. On one side if the artisans try to innovate the age-old traditional art form then it causes the depletion in the originality; on the other, no creativity pushes their traditionalism to suffer the loss of creating any global market (Dash, 2011; Agasty \& Senapati, 2015; Mohapatra \& Dash, 2011; Kumar Jena, 2010). The key component to sustaining handicrafts remains only with the adaptation of innovation and creativity. Nevertheless, the inability of the artisans to adopt innovative methods and lack of understanding the consumer needs fail to attract a sustainable market (Ghosh, 2012).

The artisan's life is at the crossroads of advanced society; thus holding an uncertain future. Moreover, technology and readymade materials have affected the traditional practices and the artisans negatively, resulting in a compromise with the raw materials and natural colour, i.e., quality gets adulterated (Tripathy, 1998; Kumar Jena, 2007; Menon, 2010). Additionally, it has dominance of male, where women execute the inferior task. Similarly, with the advent of animation and technological transformations, the pattachitra lost the artist's participation 
(Das, 2013; Dey Mullick \& Das, 2014; Rath, 2014). Apart from innovation, an increase in financial exclusion is dangerous (Beck \& Demirguc-Kunt, 2008). A financial package with a bottom-up approach can help the deprived ones; hence, financial inclusion is mandatory to rescue the vulnerable sections to grow along with the nation (Rangarajan, 2009). Moreover, financial inclusion can help in reducing the unnecessary costs, scarcity and can mitigate unfair practices in lending and saving activities (Sarma, 2012; Kumar \& Mishra, 2011).

Despite a huge number of studies on folk paintings, it lacks specific concern for financial scarcity and changing trends. This study has no recognition in international research for which it lacks a wider scope of prospects and research ideas. In addition, it has detected the problems but forgotten to form a policy structure. Moreover, literature has emphasized more on the historical backdrop, socio-religious issues, and overall traditional handicrafts in Odisha but not specifically on policy for pattachitra. Therefore, outcomes from the present study will align the trends with the financial back up by drawing policy intervention to make their life justifiable.

\section{The process in pattachitra painting}

The plea of artisans is missing and lack of debate on the key techniques, processes, and colours used in paintings has unable to disband the hidden issues. Each painting is a unique piece in itself and a margin of difference exists to make an identity. Hence, the article starts with the foundation to understand the point of financial requirement and to identify the routes of innovation. This will assist to relate it with the proposed policy to sustain their traditional art. The first raw material needed to prepare pattachitra is the canvas (patta). In the olden days, the patta was limited to the use of white cotton cloth but now choices have expanded. The cotton cloth is soaked in the tamarind seed solution and then sun-dried to prepare a canvas. With the help of wood apple gum, artisans fix these layers until the canvas becomes strong and ready for painting. Finally, they apply chalk paste as a primer to conceal the pores and scrub it with a stone to smoothen. Patta paintings have unique details of colour combinations. Earlier it used only two colours i.e. black and white. Later the artisans used colours like yellow, blood red, and green for a vibrant look or usually a combo of five colours and more. Traditionally, the colours were pigments of vegetables, leaves, and stones; but now only a few practice it. Still the natural colour remains central in pattachitra (Pandey, 1993; Das, 2013; Baral \& William, 2019).

At present, most artisans prefer a poster or synthetic colours from the market to save time. Earlier the colours were obtained like white from conch shell; black from oil lamp soot, green from neem leaves; red from a local stone known as hingula; blue colour from a stone locally called khandaneela and yellow from a stone harital. Both colours and wood apple gum are used together to prevent colour fading. The artisans use strands of mouse or squirrel's hair to make a traditional brush. This primitive brush known as tuli helps to illustrate the details on paintings (Mohapatra, 2005). However, now they use brushes available in local shops. An artisan claimed that "the skillful artisans do not make a sketch with a pencil rather they directly start painting by using brush"; but, nowadays they use HB pencil for a rough draft. Hence, this painting is a logical, methodical and theoretical in order. Among all 
the family members, the experienced artist sketches the outline, women prepare adhesive, or canvas, and their children assist or learn from them. It is a traditional family craft, which has passed from generations; it involves brainstorming, a process that requires both physical and mental labour.

\section{Methods and selection of the research area}

The current study is about the village called Raghurajpur, which is a role model of tourism but still has many unstated grievances. The village is in Puri district; it has a total population of 350 approximately with 150 households. The study considered 112 respondents out of the total. The study is a mixed method approach - comprises personal interview, observations, and rapid rural appraisal. In addition, it has adopted SWOT analysis and ABC analysis to formulate an anticipated policy. According to the Directorate of Handicrafts and Cottage Industries, Government of Orissa, survey conducted during the year 2001-2002 (dhorissa.nic. in, 2001-2002, 2005), the five districts in India i.e. Bhadrak, Khordha, Jagatsinghpur, Kendrapara, and Puri had a maximum number of artisans and productions in these art forms. However, all five had eminence at the competitive note, but artisans of Puri are the main descendants of chitrakara and have deep-rooted outlooks on this art. Hence, the reason for choosing Raghurajpur is that the art form originated here first and then it became renowned in other places. Evidently, the primary study will witness a distinctive significance because here everyone is an artist.

\section{Socio-economic status of patta artisans in the study area}

The changing trends and financial services as the key concern is interweaved with the socioeconomic context of artisans. The socio-economic data depicted that out of 112 respondents, 71 were male and the rest female, all belonging to the Hindu religion. Moreover, segregation as per titles and caste-based occupation showed that the Moharana family and the Mohapatra family are the traditional artisans and descendants of the chitrakara caste. The social parameters disclosed that at a younger age both the gender get an equal opportunity for participation in the occupation; however, a gap widens as the age increases. The assumption of marriage fits better to explain the wide gap because female participation declines due to household pressure. Additionally, the majority of respondents inherit this family occupation and it has influenced the career path of respondents belonging to 21-39 years of age. As the pattachitra connects the family type occupation, the majority belong to the joint family.

Therefore, this traditional art form retains the family relations close and intact with its convention. The pattachitra occupation plays a vital role in maintaining the family relationships where artisans work collaboratively with their near and dear ones and they do not depend on external labour. Hence, the burden of family type and handicraft also influence the total income and expenditure pattern. The analysis confirmed that their monthly income is unsatisfactory in the current trend. Only a handful of artisans, especially the businesspersons (not the traditional artisans) are in better off situation. These businesspersons are namesake artisans and especially reside in the periphery of the village; they procure finished products from traditional ones and sell them at inflated prices. In addition, majority artisans cannot 
meet the actual expenditure, household needs or generate capital and savings. Hence, this creates a rift between the household and occupational needs. Moreover, $6 \%$ of artisans under the vulnerable category manage in relatives' income and favors. Such a challenging position compels them to leave their traditional occupation or work under the sympathy of businesspersons. Apart from these, the other basic amenities like electricity, education, water, and sanitation facility is satisfactory. The unorganized financial set-up and changing trends block the prospects of this art form and their artisans.

\section{Key findings on financial scarcity and changing trends}

The artisans aspire to have long-term economic stability in their life i.e. in terms of inflow of capital, savings, and meeting expenses for a better life. It is an unsolved quest with facilities giver to cover the artisans, who are still in the last ladder to get into the total coverage of financial inclusion. Thus, the study aims to explore the financial scarcity by looking into the related factors like savings generated, preference for keeping savings, loans and advances obtained, and others. In the subsequent section, the study will cover the changing trends and innovations taking place in this art form. The patterns of designs and innovative ideas in this field are the main themes of this subject. It will show how the chitrakara community has been practicing this art form to sustain it until date.

\subsection{Analysis of financial scarcity and financial accessibility}

The analysis exhibits the insights on financial services availed and expenses incurred to match the changing trends. The data on expenses incurred revealed that the majority of artisans purchase coconut shells, bottles, palm leaf, and cloth by spending less than INR500. However, the canvas of tussar cloth, silk fabrics, wood, etc. have a varied outflow, depending on quality and demand. Therefore, the range of expense varies with the change in the type of canvas. For example, the expenses also depend on the place of procurement for example $86 \%$ of artisans incur less than INR500 for coconut canvas but the rest believe that expenses increase when they purchase from the city area. In this case, distance moderates the expenses. Similarly, for the bottle as a canvas, the price depends on traditional values; e.g., $81 \%$ artisans believe that they incur less than INR500 but the rest contradict. Such differences emerge because the later ones believe in not using alcohol, medicinal bottles, etc. because of strong ethical values. However, artisans purchasing the same bottle for more than the said price, limit to procure unused bottles from retailers.

Similarly, the label that controls canvas type woods is its quality and type. The wood of mediocre quality comes at a price of INR1500, which makes it unsustainable because it is prone to termites. The palm leaf is cheaply available because they are outdated among contemporary customers. As per data on expertise level, cloth holds the prime position followed by bottles. The reason is that cloth remained as a prime canvas in earlier days and is easily available from home itself. However, the palm leaf painting is gradually losing its market because of the trend of coconut and bottles. Hence, the majority of artisans believe that subsidy on the procurement of raw materials; like colours, bottles, coconuts, cloth, etc. can assist their expertise level congruently with the current trend. Similarly, they desire financial help to 
construct showrooms for window display and to keep their art safe and secure. Apart from this, many artisans do not belong to any formal or informal organization. The collaboration among the artisans has a wide gap i.e. limited to the boundaries of their own village or one's own workshop. This creates a communication and knowledge gap. Additionally, few have the knowledge of skill, training, and artifact scheme facility provided by the government. They mostly prefer traditional training i.e. learning from their family members. However, they desire for innovative training, reasonable pension, subsidy, and health schemes to continue their traditional work.

As the country holds a package of diversified financial sectors with the provision of financial services, the hassle-free approach is still undefined. Therefore, with the undergoing changes and technical expansion, now availing these services is possible anywhere and anytime. Moreover, these services are not the only loan focused but also mobilizes the savings into a better deposit basket. The primary study evaluated that most of the artisans have lesser income and a struggling life, as their total income from all the sources is not enough to meet their family expenses. Thus, only $39 \%$ perceive this art generates savings but the rest feel insecure. Among the saving counterparts, 13\% artisans save lesser than 2000, while only $7 \%$ of the respondents save 8000 and above, especially businesspersons. Among the respondents, male prefer a home, bank, and local credit agencies for savings; while the female prefers home, bank, and post-office. The $22 \%$ of male artisans prefer chit funds or local moneylenders just to have a "short-time more-returns" opportunity; some often fall prey to gambling. However, the low income and low capital generation compel them to avail credit facility; hence, $58 \%$ of the respondents have availed the credit or advanced facilities but fear their slow pace in repayment.

Among the loan-takers, only $4 \%$ have availed advances from cooperative society i.e. during their training programs. Moreover, $18 \%$ still believe in availing loans from the businesspersons or local moneylenders. The majority believed in taking credits from their relatives and friends. They face difficulties in availing credit facilities from the banks because of the fear of their unwarranted income and contingencies in repayment. Moreover, rigid formalities i.e. limited understanding of guidelines, corrupt practices like bribing and unhelpful attitude blocks their way. Hence, mitigation of credit problems is possible through a particular scheme for the patta artisans. Additionally, training on financial literacy can assist them to choose a better option to shield their interests (see Table 1). Hence, the lack of financial coverage makes the artisan spineless to deal with their barriers.

\subsection{Analysis of changing trends and innovation}

This topic specially deals with the quantitative, qualitative, and visual alterations taking place in the art. As we have already discussed the problems of artisans, now it is the call for dealing with the problems in the art itself to find the gaps. It includes two components i.e. permeating novelty into ethnicity and the changing medium like the use of technology, marketing website, advertisement, and partnership, etc. The study adapted ABC analysis to help the artisans in maintaining inventory to meet time demands. From the field responses, we found that there is some bestselling canvas for example- coconut patta work. Whereas, bottles and 
Table 1. Profile of financial scarcity and accessibility (source: created by authors)

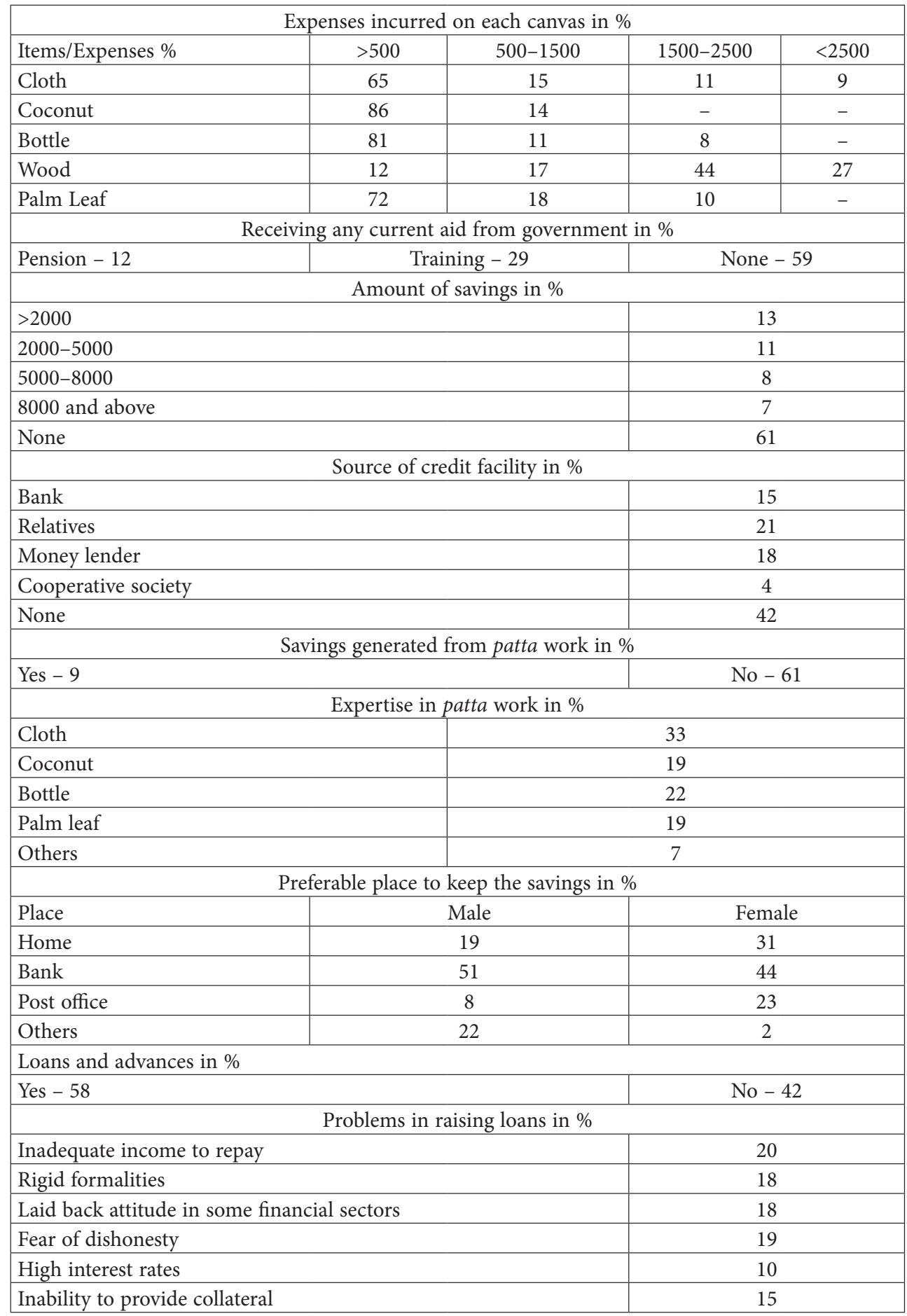


cloth patta work have the same measure. The patta work in another category is the innovative works and its demand is slowly growing i.e. items like candle-stand, vermilion box, etc. Moreover, most international tourists love to purchase pattachitra on coconut canvas because they use it as an innovative example of a recycled product.

Handicrafts have their own unique identity and utility. According to the utility and usability of pattachitra in contemporary Odisha, 39\% believed that pattachitra has household utility i.e. vermilion box, bangle stand, sari box, candle stand, and others. Similarly, 33\% believed that the utility of pattachitra seen mostly in the institution, office, and government offices. There the use of pattachitra is a way of exhibiting the accolades on the wall. The $22 \%$ of respondents said that pattachitra is good for presenting their dear ones as a token of love. Apart from selling, artisans feel more satisfied by selling their hard work at a deserving rate. From the primary analysis, 29\% of artisans believe that the price depends on the type of customer i.e. local customer, national level customer, or international level. However, businesspersons hold a bullying attitude and bluff customers to gain more. It negatively affects the tourist visits to the village and creates a bad impression on the ingenious artisans. Upon in-depth inquiry, 74\% agreed that their products sold at higher prices in the shops in the city area takes away the faith of the customers and tourists over the local artisans.

Additionally, availability and affordability are two different contexts in this art form. The availability is concerned with only the available canvas in the market but it is not necessary that it can be affordable by all. Similarly, the affordability is about the artisans being capable of procuring all types of patta canvas. It shows the qualitative and quantitative analysis of both the availability and affordability of patta canvas. On the comparison between availability and affordability, the resulted figure described that the palm leaves have lower availability than affordability, which ranges in 17 and 23 respectively. The canvas as a cloth is highly available and affordable. Whereas, the bottle as a canvas is easily available and it is marginally lower in affordability. Moreover, canvas like wood, tussar and silk fabrics under the category of "others" is easily available but its affordability is expensive for most artisans. Similarly, primary data on colour preparation congregated evidence like patta painting is currently not confined within the boundaries of only black and white because it has explored prime colours are black, yellow, green, red and white. The analysis dealt with the dominance of colours in the current trend. The primary study mined the gravity that no colours had dominance on each other.

Moreover, the choice of colours sometimes depends on the customer and on its availability. The availability for white and red colour remains in the rare position because they are collected from the environment. The artisans cannot expend so much time in searching the rare colours so either they have to appoint someone to search the colours or the timely needs of customers compel them to go for substitutes. Colours like green, black and yellow are available easily from shops or it can be prepared at home. However, $41 \%$ agreed that white colour is rare and even it is challenging to prepare. Similarly, 28\% responded that black is the second most hectic colour to prepare. Additional information from some artisans showed that now pattachitra is adding more colours to it, new colours like blue, crimson, brown, dark golden, cyan etc. Therefore, varieties of colours entice the customer to have a stare on patta exhibited on the entrances. Even the correlation of colour preparation time 
and its relation with substitute available in the market displays that, there is no correlation between the two variables. That is if there is a rise in time for preparing the natural colours, then there is no correlation with the purchase of substitute. Therefore, the p-value stands for 0.452 and it is not significant at the 0.05 level. The analysis says that the $\mathrm{H} 1$ rejected and $\mathrm{H} 2$ is true i.e. with the rise in time for the preparation of natural colours there is no increase for substitute colours. It clearly justifies that the artisan's purchase of substitute colour does not relate to the time factor rather reasons are the rare availability of some colours is an obstacle for producing other colours.

On the other hand, in the technical era, artisans wish to have some technical expertise. However, it has consequences i.e. fear of traditional skill to die out. Hence, $51 \%$ claimed against technology intervention. They kept a strong view that technology will deprive their traditionalistic ideas. Moreover, a case had already occurred that some artisans use technology to print on canvas. No control on the overuse of technology eliminates the originality and declines the clientele base. However, some technology utility can be helpful i.e. 14\% prefer to have color preparation machine to save some time and $17 \%$ demanded modern and innovative designs i.e. in association with the academicians of fashion institutes or from an international forum. In addition, online marketing website can boost recognition worldwide, but only $17 \%$ of the respondents are aware of the online marketing website on handicrafts. Therefore, robust advertising of pattachitra in media will help the unreached customers to know about this traditional art (see Table 2).

Table 2. Profile of changing trends in pattachitra (source: created by authors)

\begin{tabular}{|c|c|c|c|c|c|}
\hline \multicolumn{6}{|c|}{ Best-selling patta canvas in \% } \\
\hline \multicolumn{3}{|c|}{ Cloth } & \multicolumn{3}{|c|}{23} \\
\hline \multicolumn{3}{|c|}{ Coconut } & \multicolumn{3}{|c|}{29} \\
\hline \multicolumn{3}{|c|}{ Bottles } & \multicolumn{3}{|c|}{23} \\
\hline \multicolumn{3}{|c|}{ Palm leaf } & \multicolumn{3}{|c|}{21} \\
\hline \multicolumn{3}{|c|}{ Others } & \multicolumn{3}{|c|}{4} \\
\hline \multicolumn{6}{|c|}{ Utility of patta in Odisha \% } \\
\hline \multicolumn{4}{|c|}{ Gifts } & \multicolumn{2}{|c|}{22} \\
\hline \multicolumn{4}{|c|}{ Office } & \multicolumn{2}{|c|}{33} \\
\hline \multicolumn{4}{|c|}{ Temple } & \multicolumn{2}{|c|}{6} \\
\hline \multicolumn{4}{|c|}{ Household } & \multicolumn{2}{|c|}{39} \\
\hline \multicolumn{6}{|c|}{ Availability and affordability comparison chart } \\
\hline Canvas type & Availability & & Comparison & & Affordability \\
\hline Palm leaf & 17 & & $<$ & & 23 \\
\hline Cloth & 38 & & $\geq$ & & 37 \\
\hline Coconut & 26 & & $=$ & & 26 \\
\hline Bottles & 24 & & $>$ & & 22 \\
\hline Others & 7 & & $>$ & & 4 \\
\hline
\end{tabular}


End of Table 2

\begin{tabular}{|c|c|c|c|c|}
\hline \multicolumn{5}{|c|}{ Colours challenging to prepare in \% } \\
\hline \multicolumn{2}{|c|}{ Red } & \multicolumn{3}{|c|}{20} \\
\hline \multicolumn{2}{|c|}{ Yellow } & \multicolumn{3}{|c|}{9} \\
\hline \multicolumn{2}{|c|}{ White } & \multicolumn{3}{|c|}{41} \\
\hline \multicolumn{2}{|c|}{ Black } & \multicolumn{3}{|c|}{28} \\
\hline \multicolumn{2}{|c|}{ Green } & \multicolumn{3}{|c|}{2} \\
\hline \multicolumn{5}{|c|}{ Need for advanced technology } \\
\hline \multicolumn{3}{|c|}{ Yes $-49 \%$} & \multicolumn{2}{|c|}{ No $-51 \%$} \\
\hline \multicolumn{5}{|c|}{ Type of advanced technology in need \% } \\
\hline \multicolumn{4}{|c|}{ Colour preparation machine } & 14 \\
\hline \multicolumn{4}{|c|}{ Power hand tool } & 6 \\
\hline \multicolumn{4}{|c|}{ Innovative designs } & 17 \\
\hline \multicolumn{4}{|c|}{ Attractive packing styles } & 13 \\
\hline \multicolumn{4}{|c|}{ None } & 51 \\
\hline \multicolumn{5}{|c|}{ Online marketing websites in $\%$} \\
\hline \multicolumn{2}{|c|}{\begin{tabular}{l|l} 
Yes -17 & \\
\end{tabular}} & \multicolumn{2}{|c|}{ No -47} & not say -36 \\
\hline \multicolumn{5}{|c|}{ Correlation: Time for preparing natural colours and use of substitute colours } \\
\hline \multicolumn{3}{|c|}{$\begin{array}{c}\mathrm{X}=\text { Independent variable } \\
\text { (time taken to prepare natural colours) } \\
\mathrm{Y}=\text { Dependent variable (use substitute as colours) }\end{array}$} & $\begin{array}{c}\text { Time for } \\
\text { preparing colours }\end{array}$ & Substitute used \\
\hline \multirow{6}{*}{$\begin{array}{l}\text { Spearman's } \\
\text { rank coefficient } \\
\text { correlation }\end{array}$} & \multirow[t]{3}{*}{$\begin{array}{c}\text { Time for } \\
\text { preparing colours }\end{array}$} & $\begin{array}{l}\text { Rank correlation } \\
\text { coefficient }\end{array}$ & 1.000 & .072 \\
\hline & & Sig. (2-tailed) & . & .452 \\
\hline & & $\mathrm{N}$ & 112 & 112 \\
\hline & \multirow[t]{3}{*}{ Substitute used } & $\begin{array}{c}\text { Rank correlation } \\
\text { coefficient }\end{array}$ & .072 & 1.000 \\
\hline & & Sig. (2-tailed) & .452 & . \\
\hline & & $\mathrm{N}$ & 112 & 112 \\
\hline
\end{tabular}

\section{6. $\mathrm{ABC}$ analysis of pattachitra raw materials}

The hand made products are not free from mistakes and duplicity. Hence, the extent of orders contracted, the rejection, and defects are totally interrelated components that need a mention and analysis through the ABC model. The primary data showed that $34 \%$ of artisans get orders less than the range of five in a month. Only $31 \%$ get orders ranging from $5-15,22 \%$ get orders ranging from 15-25 and 13\% get more than 25 orders. On the other hand, 51\% of the respondents have patta work rejection of 5-10 in a month. There are various reasons for rejections like either it is due to late completion of work, due to a defective piece or due to changed customer preferences and mindset. However, such rejections make them dependent on the intermediaries. Additionally, 38\% of artisans believe that they do not create any defective piece because of their traditional experience in this field. From the rest, $34 \%$ of the 
Table 3. Profile of order, rejection, defects and storage facilities (source: created by authors)

\begin{tabular}{|c|c|c|c|}
\hline \multicolumn{2}{|c|}{ Number of orders received (monthly) } & \multicolumn{2}{c|}{ Rejection (monthly basis) } \\
\hline Range & Percentage & Range & Percentage \\
\hline$>5$ & 34 & $>5$ & 34 \\
\hline $5-15$ & 31 & $10-15$ & 51 \\
\hline $15-25$ & 22 & 15 \& above & 2 \\
\hline$<25$ & 13 & \multicolumn{2}{|c|}{ Storage facilities in \% } \\
\hline Number of defects (monthly) & \multicolumn{2}{|c|}{ Showroom } & 19 \\
\hline Range & Percentage & Government provided & 2 \\
\hline$>5$ & 28 & Shelter & 20 \\
\hline $5-10$ & 34 & Own godown & 59 \\
\hline None & 38 & \multicolumn{2}{c}{ Home } \\
\hline
\end{tabular}

respondents have defects ranging from 5-10 only and 28\% of respondents have defects on their patta less than 5 only (see Table 3 ). Therefore, in order to maintain a balance among the entire three components, the study takes into account the $\mathrm{ABC}$ analysis related to inventory management. The $\mathrm{ABC}$ analysis will help in understanding the balance of two levels i.e. firstly, the volume and secondly the value. Both the value and volume of the inventory will help the artisans to minimize the rate of rejection and defects. This management analysis will also help in increasing the number of orders in other ways.

The analysis considered three important materials for pattachitra i.e. natural colors, patta or the canvas and glue (tamarind and wood apple adhesive). There are three categories in $\mathrm{ABC}$ analysis i.e. A, B, and C. From the responses, natural color suits "A" category, i.e. the material has less volume but greater value i.e. volume $10 \%$ and value is $50 \%$. Whereas the patta or the canvas is the "B" category, both volume and value are equal i.e. $40 \%$. Moreover, the final component is the application of glue i.e. " $\mathrm{C}$ " category, where the volume is more but the value is less. Therefore, the analysis states that the artisans shall focus on the "A" category most since both monetary and customer satisfaction depends on this category. If the colors are quickly available and its inventory well maintained then it can fulfill the customer's choice. The second category i.e. " $\mathrm{B}$ " maintained in both levels so it can be more effective in nature. The last category is manageable at any time; therefore, artisans can make a greater volume of adhesive and store it to save time for other work (see Figure 1).

\section{Innovation in pattachitra: ideas of integrating novelty with ethnic roots}

The patta art form has undergone several changes and with its traditional form, it has integrated novelty for retaining sustainability. From the primary study, collected responses show the innovative ideas (see Table 4) that the artisans eagerly want to experiment and implement. However, this will be impossible if the glitches exist in attaining finances or raw 


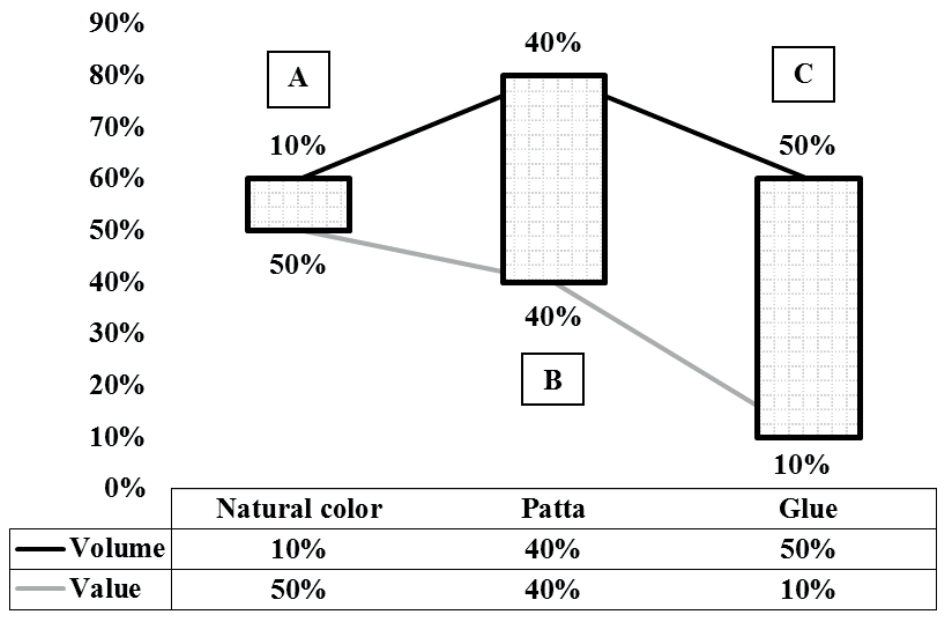

Figure 1. ABC Analysis (source: created by authors)

Table 4. Ideas of artisans: Probable innovative products (source: created by authors)

\begin{tabular}{|l|}
\hline Pattachitra on bangles \\
\hline Patta book cover \\
\hline Patta designs on bookshelf, wrist watches \\
\hline Curtain, bed linen, pillow covers \\
\hline Tea trays, tea kettle \\
\hline Dining table and chairs, doors, clock \\
\hline Earrings, necklace, spectacle frames \\
\hline Purse and luggage bags laptop \& mobile cover \\
\hline
\end{tabular}

materials. In addition, observed changes showed the existence of innovation. In a serial collection, it shows traditional patta - the palm leaf engravings, Lord Jagannath wall hanging mask, eco-friendly cow dung toys, and papier-mâché, black and white pattachitra; traditional five-colour combination pattachitra, old sample of palm leaf pattachitra, meditating Buddha patta, love story of Radha and Lord Krishna (in dance form) a portion from Krishna Leela (traditional narratives of Lord Krishna's life), and patta paintings on wall to prevent evil eyes (see Figure 2).

Some of the innovative forms are - candle stand, tortoise for good luck, Lord Jagannath wall hanging for decoration, patta teakettle, and polling necklace for style and as a token of joyful journey used in a vehicle. The patta work on tussar sari, bangle box for gifting or storing bangles, and vermilion box (locally known as sindoora dabaa) for married women. The elephant papier-mâché beautifully coloured with minute decorations, the hanging bird wind chimes; the coconut canvas - in Odisha coconut is very propitious, and this dried one 


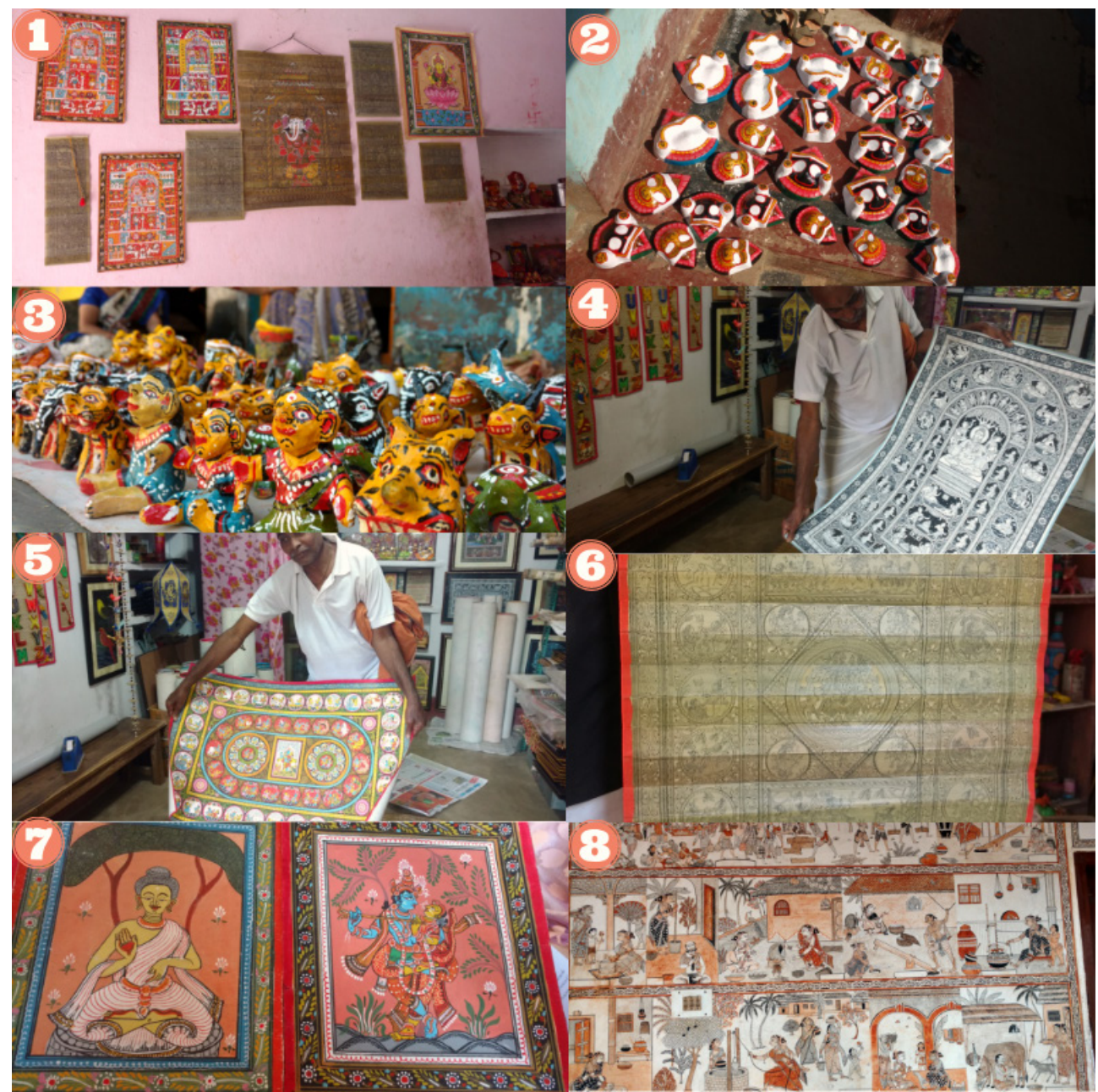

Figure 2. Collection of traditional patta paintings (source: created by authors)

makes attractive artifacts. The pattachitra made on the door, usually used by hotel and restaurants to give an exotic look; expressional papier-mâché and paper masks in vibrant shades. Another novel idea is the patta on the wall clock, besides that a papaya patta stand; bottle patta paintings used as a flower vase and garden decoration; the lamp shade and finally a sari box for a gift and storing purpose (see Figure 3). There are some visuals of artefacts in their raw state like white patta (canvas), colours, use of cow dung on papier-mâché, sun-dried papier-mâché and cow dung toys, dried polang balls, dried palm leaf, homemade natural colours inside coconut shells, chisel used to engrave designs on the palm leaf and bangle box structure (see Figure 4). 


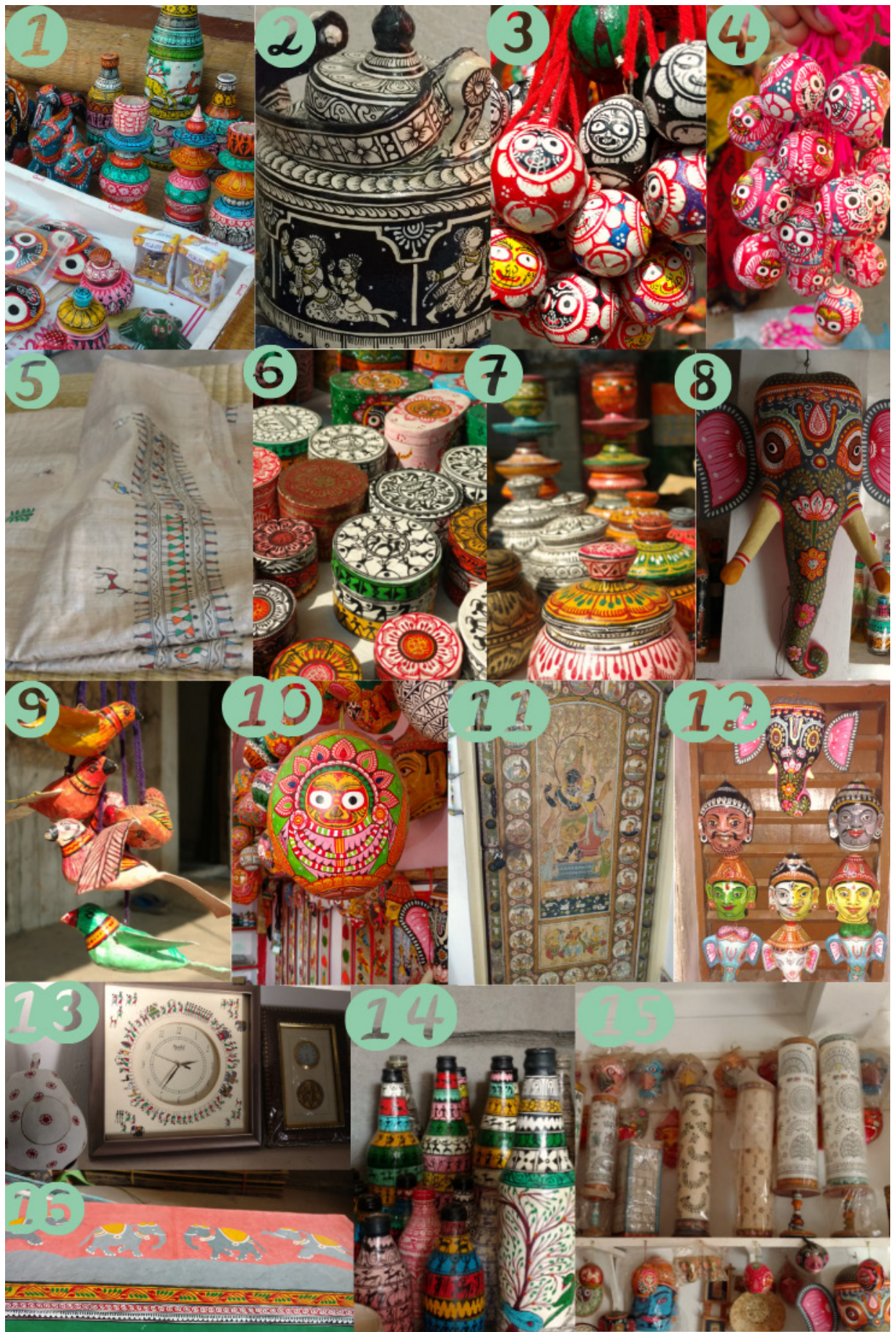

Figure 3. Collection of modern patta paintings (source: created by authors) 


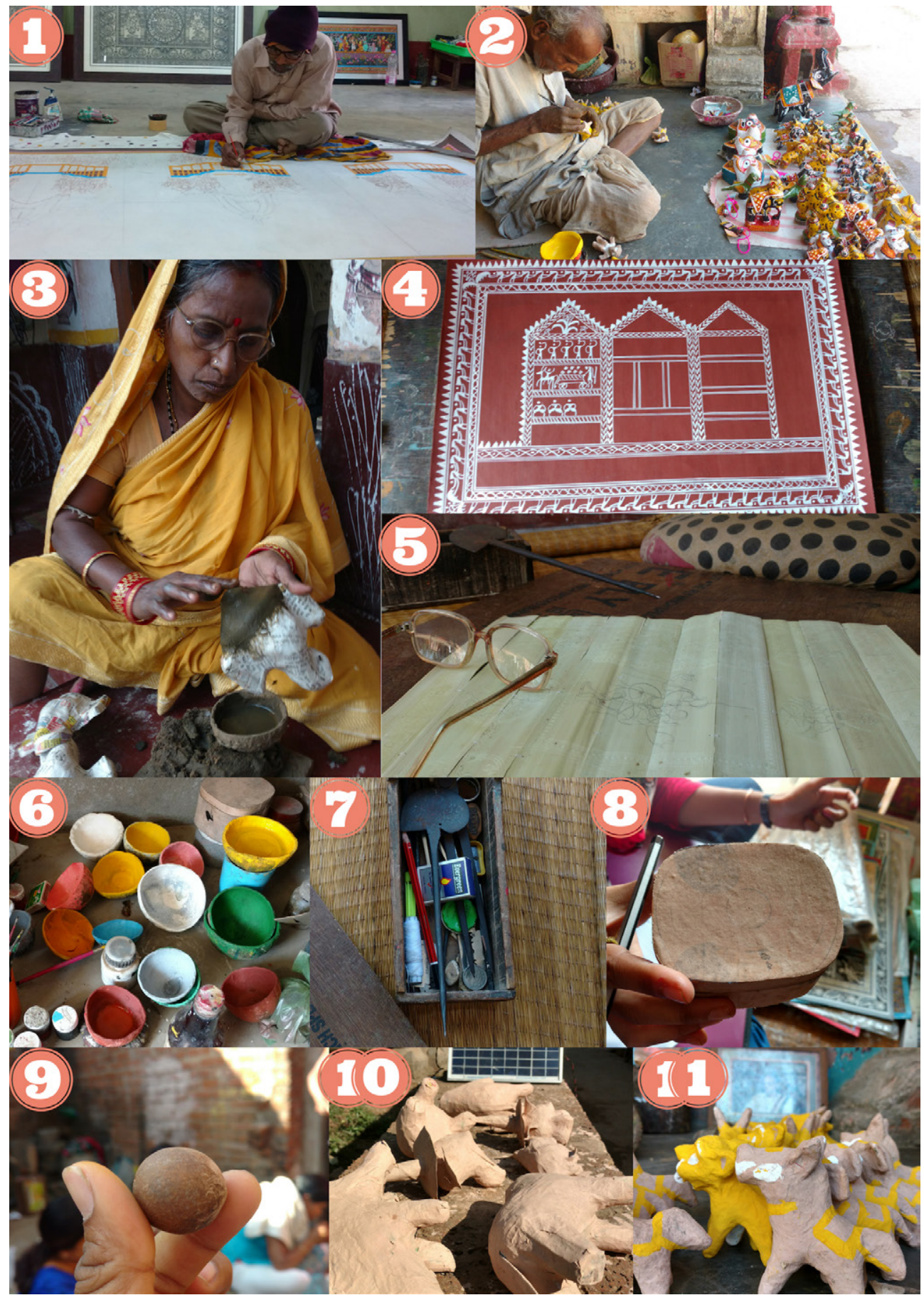

Figure 4. Collection of patta pictures in raw form (source: created by authors) 


\section{Impact of creative pattachitra art on the culture of South Asian region}

From the old days till now, the evolution taken place in the creative paintings has some forms of resemblance worldwide. Among the variety of South Asian arts, the most colourful yet one among the indigenous one is the patta paintings ( $\mathrm{Ku}, 2014)$. Though the paintings differ in names, techniques, and expressions, it connects different parts of the world through themes like religion, identity or caste-based/community practice, gender roles, rituals, geographical area, and purpose. For example, Thangkas (also famous in Tibet) and Bhutanese wall painting of Bhutan expresses the Buddhist culture and propagates religious learning. The history of similar paintings also supports the cultural exchange that took place in many places, including Odisha, when the Buddhist preachers visited to spread Buddhism culture (Behrendt, 2014). On reflecting the ritual, caste-based practice, and gender roles (similar to pattachitra), Mithila art of Nepal shows the deep-rooted daily practices of women in the Maithils community. Unlike the Maithils community, pattachitra art in Odisha is dominated by male members. Such artworks firmly hold the family bond through creative practices in all auspicious occasions such as birth, wedding, and festivals (Weise, 2012).

Similarly, the paintings from Bangladesh represent the symbolic beauty of the rural folks and its geographical identity, i.e., motifs reflecting the land and its people. This painting serves the purpose of narrating stories through multi-coloured pictures to bring awareness and disperse information to rural audiences (Sharothi, 2014). Likewise, paintings from Pakistan reveals various transition, i.e., starting from an artists' struggle for identity towards contemporary socio-political theme (Syed \& Abdullah, 2015). Paintings of Sri Lanka are also highly inspired by religion, cultural, natural settings and lifestyles (Bandara, 2009). Somewhere, all these paintings mirror the Indian culture, and the country also absorbs the impacts to restate and retain the worth of its art. Undeniably, these paintings are not functioning in isolation because the techno-global era has embedded itself in society. Now, the folk paintings are not only limited to culture; rather, it is evolving with the changes taking place in society, technology, and economy.

The traditional skills of painting that used to pass through generations at home are now available for the outside world. The conventional learning has expanded itself to reduce ruralurban migration and generate self-employment (Gough \& Rigg, 2012). Today, the practice is not only limited to the complex set of cultures but also develops new meanings by reflecting the civilized culture of modern society. To sustain the traditional art with modernity, artisans are stressing on contemporary issues and public welfare (Chakrabarti, 2008) to tell realism involved in the community. From the culture of spirituality and religiosity, it has changed to material culture and is positively creating a scope of financial empowerment for rural youths and women.

However, to tackle the technological, financial, and socio-economic barriers, such traditional paintings need to adopt the changing needs and customers' preferences. In addition to innovation, borrowing patterns and finance also influence the conventional techniques used by the communities (Gosselain, 2000; Gandon, Coyle, \& Bootsma, 2014). Sadly, the easy-made alternatives, stiff competition, lack of capital due to low price, and encroachment of technology devalues the creative practices. It also demotivates the young artisans to learn 
or to contribute any traditional work (Mehra, Mathur, \& Tripathi, 2019). Moreover, weak market linkages and inadequate access to other resources like finance and technical support obstruct the economy, and in return, it hinders the progress of traditional artisans, and their cultural traits (Wherry, 2006) to make way for creativity. The idea of digitizing such artworks, keeping it in a museum, or integrating it with technology may look helpful, but it can only retain the visual appearance, external needs, and short-term economy that is highly unsustainable.

Slowly, this will disturb the identity of rituals, community, and region; it will also restrict family bonds and will weaken the ethnic preparations in festivals and auspicious occasions; finally, it will collapse the cultural exchange among the nations. Therefore, the present research provides a specific concern for the finance and changing trends because it also revolves within the layers of historical, creative, socio-economic and cultural background. To preserve cultural heritage, countries need to devise policies (Grobar, 2019). As the policymakers are stressing on handicraft development (Prajapati \& Narayan Biswas, 2011) to accrue its benefits in Indian society, culture, and economy, the paper also extends its efforts to sustain such similar paintings globally through its anticipated policy framework.

\section{The anticipated policy framework and SWOT analysis}

For framing the policy, the context has embraced the elements of earlier sections like market linkage, colour preparation problems, need of intervention of technology, management of inventories and raw materials, orders and rejections and the lack of online marketing initiation and others. It has also helped to chalk out the SWOT analysis (see Table 5) to deter contingencies and to tap the possible opportunities. From the above sections, it is clear that artisans lack specific provisioning of secured financial aid, which creates limited resources and lower returns. This in return creates a lack of organized marketing channels, inadequate funds to construct storeroom or showroom, shortage of funds and raw materials challenges any initiative towards innovation, and lack of promotional activities makes them incompetent to tackle their profession in a globalized era.

In addition, the presence of exploitative intermediaries and forced intrusion of businesspersons as a fake artisan divert the tourists from the deserved group of artisans. Moreover, no specific health schemes for the aged artisans make them live in absolute insecurity. Therefore, a standardized and liberalized policy can rescue them from the crossroads and support their traditional practice. As per the authors' suggestion, a credit payment scheme for the artisans in Raghurajpur village is proposed. However, the suggestion is a preliminary idea of the author and making it noticeable to the policy-makers will help to establish it as a solid scheme (see Table 6). The artisans can avail advances as per their financial soundness. The repayment month is fixed according to their financial stability. Moreover, additional benefits will act as complementary and will help in faster repayment. It can help them to balance their income, outcomes, and creativity in an equivalent form. Hence, such a scheme is expected to work specifically for the patta artisans, to rescue them from the crossroads of financial scarcity and changing trends. 
Table 5. SWOT analysis (source: created by authors)

\begin{tabular}{|c|c|c|c|}
\hline STRENGTHS & WEAKNESSES & OPPORTUNITIES & THREATS \\
\hline $\begin{array}{l}\text { - Artistic value of } \\
\text { every patta work; } \\
\text { - Utilization of local } \\
\text { natural resources; } \\
\text { - Maintaining Odis- } \\
\text { ha’s culture; } \\
\text { - Recognition as } \\
\text { "heritage village"; } \\
\text { - High expertise } \\
\text { level; } \\
\text { - Minimum use of } \\
\text { labour; } \\
\text { - Minimum raw ma- } \\
\text { terials; } \\
\text { - Green and clean } \\
\text { village, no open } \\
\text { defecation. }\end{array}$ & $\begin{array}{l}\text { - Female artisan } \\
\text { work as assistant; } \\
\text { - Lack of storage and } \\
\text { storerooms; } \\
\text { - No security for old } \\
\text { aged and widows; } \\
\text { - Reduced propor- } \\
\text { tion in inheriting } \\
\text { traditional occu- } \\
\text { pation; } \\
\text { - Same training pro- } \\
\text { vided repeatedly; } \\
\text { - Youths involved } \\
\text { in non-productive } \\
\text { work; } \\
\text { - Less investment but } \\
\text { less earning also; } \\
\text { - Non-availability of } \\
\text { special raw materi- } \\
\text { al store. }\end{array}$ & $\begin{array}{l}\text { - Channelize products } \\
\text { through online market- } \\
\text { ing websites; } \\
\text { - More scope for research } \\
\text { and development; } \\
\text { - Recruitment of institute } \\
\text { based designers in vil- } \\
\text { lage (Interns); } \\
\text { - Scope for innovations } \\
\text { and self-employment; } \\
\text { - Export ability art form; } \\
\text { - Memorandum of un- } \\
\text { derstanding with inter- } \\
\text { national forum to attain } \\
\text { worldwide recognition } \\
\text { and assistance; } \\
\text { - Eco-cottage holiday stay } \\
\text { facilities to earn funds } \\
\text { to invest on artisan's } \\
\text { livelihood; } \\
\text { - Create official arti- } \\
\text { san-client feedback } \\
\text { system. }\end{array}$ & $\begin{array}{l}\text { - Presence of interme- } \\
\text { diaries in periphery } \\
\text { of village; } \\
\text { - Unawareness of } \\
\text { handicraft schemes } \\
\text { and benefits; } \\
\text { - Exploitation by chit } \\
\text { funds; } \\
\text { - Incapable to handle } \\
\text { timely orders, lack of } \\
\text { marketing strategies; } \\
\text { - Lack of financial } \\
\text { literacy; } \\
\text { - Exploitative technol- } \\
\text { ogies can bring tra- } \\
\text { ditional patta to the } \\
\text { edge of extinction; } \\
\text { - Low income increas- } \\
\text { es threat of shifting } \\
\text { of occupation; } \\
\text { - Dominance of local } \\
\text { politics diverts ar- } \\
\text { tisans from actual } \\
\text { work. }\end{array}$ \\
\hline
\end{tabular}

Table 6. Odisha chitrakara scheme (anticipated policy framework) (source: created by authors)

\begin{tabular}{|c|c|c|l|}
\hline $\begin{array}{c}\text { Credit/ } \\
\text { advances }\end{array}$ & $\begin{array}{c}\text { Financial } \\
\text { soundness }\end{array}$ & Repayment & \multicolumn{1}{|c|}{ Benefits } \\
\hline 1000 & Poor & $\begin{array}{c}2 \text { and } 1 / 2 \\
\text { months } \\
@ ~ 2 \%\end{array}$ & $\begin{array}{l}\text { Credit provided to purchase canvas, deposit scheme with } \\
\text { 3\% interest rate for 5 months and special participation in 3 } \\
\text { exhibition (travelling and food cost to be borne by agency) }\end{array}$ \\
\hline $2000-3000$ & Moderate & $\begin{array}{c}2 \text { and } 1 / 2 \\
\text { months } \\
\text { @ 2\% }\end{array}$ & $\begin{array}{l}\text { Credit to purchase colours and canvas, deposit scheme with } \\
\text { 3\% interest rate for 5 months, participation in 3 exhibition } \\
\text { (travelling cost and food cost to be borne by agency) }\end{array}$ \\
\hline $\begin{array}{c}9000- \\
12000\end{array}$ & Sufficient & $\begin{array}{c}2 \text { months } \\
\text { @ 2.5\% }\end{array}$ & $\begin{array}{l}\text { Credit to purchase colours, canvas and deposit with 3\% } \\
\text { interest rate for 4 months, participation in 3 exhibition }\end{array}$ \\
\hline $\begin{array}{c}13000- \\
18000\end{array}$ & Good & $\begin{array}{l}\text { Credit for procuring all raw materials (with choice) plus } \\
\text { individual advertising facilities, deposit for 3 months with } \\
\text { interest of 3\% }\end{array}$ \\
\hline 20000 & Very good $3 \%$ & $\begin{array}{l}\text { Credit for procuring all raw materials (with choice), } \\
\text { advertising facilities, and deposit for 3 months with 4\% } \\
\text { interest (money to be utilized for establishing individual } \\
\text { showrooms) }\end{array}$ \\
\hline @onths & $\begin{array}{l}\text { Credit for procuring all raw materials (with choice) and } \\
\text { renovating or constructing showrooms, deposit for 3 } \\
\text { months at 4\% interest, advertising and deal with online } \\
\text { marketing }\end{array}$ \\
\hline
\end{tabular}




\section{Conclusions}

The obvious evidence from the primary survey depicts that pattachitra is the cultural heritage and treasure of Odisha. It is very essential to protect such art forms for our future generations to adore their culture. The struggling artisans can get complementary benefits by availing the short-term advances, which will act as a medium to progress and not a burden. It is also necessary to make the artisans aware of the encroachment of exploitative techniques. The village must be monitored and strict control should follow against the overuse of technology. Extension of development towards this art form can bring up novel ideas for example - a technology to extract natural colour can help saving time. Additionally, the artisans must be provided a subsidy for raw materials i.e. on canvas and natural colours. The subsidy can help them to save extra expenses and it can save time for their artwork. Such initiatives will indirectly curtail the unfair means spread by the intermediaries. The village must also initiate to make copyrights on innovative designs to protect the artisan's value, creativity, and rights.

It is much essential to make the functions of non-governmental organizations more robust. The non-governmental organizations working for handicraft sectors must be given due priority in the state, to strengthen the cultural artifact in the near future. Their collaboration with local artisans can help them to participate in worldwide forums. Likewise, government interventions can help to promote self-help groups especially among the women, it can help to promote gender equality in practicing the art form. Moreover, young youths must be encouraged in technically based training i.e. opening up a new website for their family occupation and joining a partnership with big online websites through government interventions. Lastly, this study has the scope for extending research from tourism, health, and educational perspective. There are so many artisans, who feel uncovered by the health benefits. Long hours spent on preparing and processing the ideas also needs equal concern for health. Moreover, boosting tourism will help the artisans to come up with more creative ideas, which will subsequently create their financial soundness. On educational perspectives, tie-ups with design institutions and fashion industries can help the entrepreneurs, clients, and artisans to create a hub of creativity and trend. Instead of benefits in the hands of few, promoting strong export activities of creative ideas to different corners of the world can help patta artisans to sustain this practice.

\section{Acknowledgements}

We thank all the respondents for sparing their precious time in answering our queries to the best of their knowledge. We acknowledge the efforts of Creativity Studies editor(s) and anonymous reviewers for providing us their constructive comments.

\section{Funding}

The authors did not receive any financial support regarding the present research, authorship, and/or publication of this article. 


\section{References}

Agasty, M. P., \& Senapati, J. (2015). Handicrafts industries in Odisha: problems and prospects. International Journal of Multidisciplinary Research and Development, 2(5), 517-521.

Bandara, R. D. S. M. (2009). Landscape as depicted in Srilankan traditional paintings with special reference to Kandyan period paintings (Partial Master Thesis). University of Moratuwa. Moratuwa, Sri Lanka. Retrieved from http://dl.lib.mrt.ac.lk/bitstream/handle/123/11139/103413. pdf? sequence $=1$ \&isAllowed $=y$

Baral, B., \& William, A. (2019). Patachitra Painting - Orissa: The Art of Making Picture on Cloth, D'Source. Retrieved from http://dsource.in/sites/default/files/resource/patachitra-painting-orissa/ downloads/file/patachitra_painting.pdf

Behrendt, K. (2014). Tibet and India: Buddhist Traditions and Transformations. The Metropolitan Museum of Art Bulletin, 71(3), 1, 4-48.

Beck, Th., \& Demirguc-Kunt, A. (2008). Access to finance: an unfinished agenda. The World Bank Economic Review, 22(3), 383-396. https://doi.org/10.1093/wber/lhn021

Chakrabarti, A. K. (2008). The tradition of scroll paintings with a special emphasis on Lord Jagannatha. Orissa Review, November, 13-18.

Das, N. (2013). Patachitra of Orissa: a case study of Raghurajpur village. An Online Journal of Humanities \& Social Science, 1(4), 247-251.

Dash, M. (2011). Marketing of Orissa handicrafts: a study on challenges and opportunities. EXCEL: International Journal of Multidisciplinary Management Studies, 1(2), 47-63.

Dey Mullick, P., \& Das, A. (2014). Puri: an overview on the space, potential and possibilities for social research. Radix International Journal of Research in Social Science, 3(11), 1-7.

dhorissa.nic.in. (2001-2002). Craft-wise Artisans and production. Retrieved from http://dhorissa.nic. in/hc_artsian.htm

dhorissa.nic.in. (2005). Directorate of handicrafts and cottage industries, government of Orissa. Retrieved from http://dhorissa.nic.in/

Gandon, E., Coyle, Th., \& Bootsma, R. J. (2014). When handicraft experts face novelty: effects of shape and wheel familiarity on individual and community standardization of ceramic vessels. Journal of Anthropological Archaeology, 35, 289-296. https://doi.org/10.1016/j.jaa.2014.06.008

Ghosh, A. (2012). Triggering innovation and creativity in traditional handicrafts sectors - an Indian perspective. Management Insight, 8(1), 67-71.

Gosselain, O. P. (2000). Materializing identities: an African perspective. Journal of Archaeological Method and Theory, 7(3), 187-217. https://doi.org/10.1023/A:1026558503986

Gough, K. V., \& Rigg, J. (2012). Reterritorialising rural handicrafts in Thailand and Vietnam: a view from the margins of the miracle. Environment and Planning A: Economy and Space, 44(1), 169-186. https://doi.org/10.1068/a44175

Grobar, L. M. (2019). Policies to promote employment and preserve cultural heritage in the handicraft sector. International Journal of Cultural Policy, 25(4), 515-527. https://doi.org/10.1080/10286632.2017.1330887

Kanungo, A. (2013). Unity in diversity: the uniqueness of Jagannath culture of Odisha. Orissa Review, July, 57-66.

Kanungo, G. (1964). Utkalara Citrakalāa. Bhubaneswar: Odisha Lalitkala Academy.

$\mathrm{Ku}, \mathrm{H}$. (2014). Representations of ownership: the nineteenth-century painted maps of Shatrunjaya, Gujarat. South Asia: Journal of South Asian Studies, 37(1), 3-21. https://doi.org/10.1080/00856401.2013.852289

Kumar, Ch., \& Mishra, S. (2011). Banking outreach and household level access: analysing financial inclusion in India. Retrieved from https://pdfs.semanticscholar.org/558f/f506e0b4096f87a37d3796a868c34a448735.pdf 
Kumar Jena, P. (2010). Indian handicrafts in globalization times: an analysis of global-local dynamics. Interdisciplinary Description of Complex Systems, 8(2), 119-137.

Kumar Jena, P. (2007). Orissan handicrafts in the age of globalisation: challenges and opportunities. Orissa Review, November, 12-16.

Mehra, A., Mathur, N., \& Tripathi, V. (2019). Sahaj crafts: the challenge of alleviating poverty in Western Rajasthan. Emerald Emerging Markets Case Studies, 9(1), 1-45. https://doi.org/10.1108/EEMCS-06-2018-0099

Menon, V. (2010). Art of marketing village crafts: challenges in applying quantitative marketing to resist recession. International Review of Business Research Papers, 6(5), 196-205.

Ministry of Textiles. (1989). The report of the task force on "handicrafts" for the eighth five year plan. New Delhi: Government of India.

Mitra, R. (1875). The antiquities of Orissa. Vol. I. Calcutta: C. B. Lewis, at Baptist Mission Press.

Mitra, R. (1880). The antiquities of Orissa. Vol. II. Calcutta: W. Newman \& Co.

Mohanty, B. (2011). Pata-paintings of Orissa. New Delhi: Publications Division, Ministry of Information and Broadcasting, Government of India.

Mohapatra, T. (2005). Pattachitra - an indigenous technique. Orissa Review, November, 34-36.

Mohapatra, S., \& Dash, M. (2011). Problems associated with artisans in making of handicrafts in Orissa, India. Management Review: An International Journal, 6(1), 56-81.

Pandey, S. K. (1993). Indian rock art. New Delhi: Aryan Books International.

Pathy, D. (1990). Traditional paintings of Orissa. Bhubaneswar: Working Artists Association of Orissa.

Prajapati, K., \& Narayan Biswas, S. (2011). Effect of entrepreneur network and entrepreneur self-efficacy on subjective performance: a study of handicraft and handloom cluster. The Journal of Entrepreneurship, 20(2), 227-247. https://doi.org/10.1177/097135571102000204

Rangarajan, C. (2009). Reduce economic disparities, improve social indicators. Retrieved from http:// inclusion.skoch.in/story/557/reduce--economic-disparities-improve-social-indicators-857.html

Rath, N. (2014). Isolation or integration: the plight of the women craft workers in the era of globalisation. Madhya Pradesh Journal of Social Sciences, 19(1), 53-65.

Sarma, M. (2012). Index of financial inclusion - a measure of financial sector inclusiveness. Berlin Working Papers on Money, Finance, Trade and Development. Working Paper No. 07/2012. Berlin: Competence Center "Money, Finance, Trade and Development".

Sharothi, K. F. A. (2014). National centre for folk arts, Dhaka, Bangladesh. Seminar II (Partial Bachelor Thesis). BRAC University. Dhaka, Bangladesh. Retrieved from https://core.ac.uk/download/ pdf/61804928.pdf

Syed, K., \& Abdullah, S. (2015). Chronicling Pakistan's art movements from traditional to contemporary, 1960-2011. Wacana Seni: Journal of Arts Discourse, 14, 31-58.

Tripathy, M. (1998). Folk art at the crossroads of tradition and modernity: a study of Patta painting in Orissa. Journal of the Anthropological Society of Oxford, 29(3), 197-211.

Upadhyay, M. N. (1976). Handicrafts of India. Secunderabad: Swarajya Printing Works.

Weise, K. (2012, 27-29 November). Safeguarding traditional painting skills in Nepal. Proceedings of the International Conference "Human Resources Development for the Transmission of Traditional Skills: Building Decoration with a Focus around Painting and Colouring". International Conference "Human Resources Development for the Transmission of Traditional Skills: Building Decoration with a Focus around Painting and Colouring" (pp. 43-56). Nara, Japan.

Wherry, F. F. (2006). The nation-state, identity management, and indigenous crafts: constructing markets and opportunities in Northwest Costa Rica. Ethnic and Racial Studies, 29(1), 124-152. https:// doi.org/10.1080/01419870500352454 


\title{
KÜRYBINEI PATTACHITRAI TAIKOMA POLITIKOS SISTEMA FINANSINIŲ IŠTEKLIŲ TRŪKUMO IR KINTANČIŲ TENDENCIJŲ SĄLYGOMIS
}

\author{
Pallavi KANUNGO, Narayan SETHI, Pritam BISWAL
}

\section{Santrauka}

Šiame straipsnyje pristatomi amatai, žinomi kaip pattachitros menas, personifikuojantis Odišos kultūrą ir dvasinius ritualus. Pattachitra - tai gerai žinoma tradicinès tapybos rūšis, plètojama Ragurajpuro kaime, Puryje, Odišoje (ankstesnis pavadinimas - Orisa), Rytų Indijoje. Tyrimo tikslas - išnagrinèti amatininkams skiriamą finansinę paramą ir finansinių išteklių trūkumo keliamas problemas, su kuriomis jie susiduria, bei suprasti jų skirtingus požiūrius, siekiant palaikyti šią tapybos rūši kintančių tendencijų sąlygomis. Tyrimas grindžiamas mišriu metodu, apimančiu asmeninius interviu, stebejimus ir sparčiai atliktą kaimo vertinimą. Tyrime taip pat taikoma SSGG analizè (stiprybès, silpnybès, galimybès ir grèsmès) ir VGA analizė, kurios padejo rengiant politikos sistemą. Galiausiai straipsnis grindžiamas iliustruotais faktais, siekiant pademonstruoti inovatyvius požiūrius, pritaikytus šiam tradiciniam menui palaikyti.

Reikšminiai žodžiai: amatininkai, kintančios tendencijos, finansinių išteklių trūkumas, Odiša, pattachitra. 